\title{
Evaluation of booster additive with different DOC body weight on Broiler production performance in closed house
}

\author{
Muharlien Muharlien ${ }^{1)}$, Edhy Sudjarwo ${ }^{1)}$, Dyah Lestari Yulianti*1) and Heni Setyo Prayogi ${ }^{1)}$ \\ 1) Faculty of Animal Science, Brawijaya University, Jl. Veteran, Ketawanggede, Kec. \\ Lowokwaru, Kota Malang, Jawa Timur, Indonesia, 65145
}

Submitted: 17 October 2020, Accepted: 30 November 2020

\begin{abstract}
This experiment was carried out in a $7.500 \mathrm{~m}^{2}$ poultry closed house located between the geographical coordinates $7^{\circ} 21^{\prime}-7^{\circ} 31^{\prime}$ south latitude and $110^{\circ} 10^{\prime}-111^{\circ} 31^{\prime}$ west longitude and an average altitute of $654 \mathrm{~m}$, from July to August 2020. The chickens were placed in 24 pens measuring $1 \mathrm{~m}^{2}$ each at stocking density of 4 chickens $/ \mathrm{m}^{2}$. This study aimed at evaluating the effect of three initial weights (chick weight on first day of experiment) and two types of mixed feed on broiler performance. A total 96 day old chicks strain CP 707 derived from the same flock of breeders, was distributed in completely randomized experimental design with 3 (initial weight) by two types of mixed feed, five replications per treatment. The feed was complete feed produced by PT. Charoen Pokphand Indonesia Tbk. Complete feed was given based on the maintenance phase, include BR0 (1-7 days old), BR1 (8-21 days), and BR2 (>21 days). The booster additive was a commercial product. Initial weights were classified as light (37-41 g), medium (42-46 g) and heavy ( $>47 \mathrm{~g}$ ), whereas mixed feed (with and without additive booster) were used as daily chicken feed. Data were analyzed by ANOVA and means were compared by Tukey's test at $95 \%$ confidence level. Initial weight and types of mixed feed have no effect on feed consumption, body weight gain, feed conversion, dan production index.
\end{abstract}

Keywords: Additive booster; closed house; initial body weight; production performance

\footnotetext{
*Corresponding Author: dyahlestariyulianti@gmail.com
} 


\section{INTRODUCTION}

DOC quality is a very important factor in the industry because it has a direct relationship with broiler performance (Decuypere et al., 2001). DOC quality is an indicator of broiler productivity. DOC quality can be evaluated and assessed based on several traits such as color, yolk residue, leg form, beak shape, DOC hatching weight, body weight without egg yolk residue, and DOC length (Ipek and Sözcu, 2013). Some researchers have found a positive correlation between body length of DOC and body weight of broilers at 42 days (Hill, 2001; Meijerhof, 2006; Molenaar et al., 2008). Molenaar et al. (2008) found that an increase in body length of male broiler DOC from eggs with the same weight and hatch time indicated an increase in body weight during rearing.

Some researchers have found that DOC weight affects the performance of production up to harvest (Al-Murrani, 1978; Whiting and Pesti, 1984; Mafeni et al., 1986). Meanwhile, other studies show, for broilers, DOC weight does not succeed in realizing rapid growth at the beginning of the growth period and has very little effect on economic value and efficiency (Morris et al., 1968; Pinchasov, 1981). Information on how DOC weight affects growth after hatching is still very minimal.

Growth hormone plays a very important role for skeletal muscle growth, metabolism, immunity, reproduction, regulation of other hormones and other aves species (Haleuy et al., 1996; Foster et al., 1997; Hodik et al., 1997). The thyroid hormones, tridothyrorine (T3) and thyroxine (T4) regulate the activity of several enzymes in metabolic activities that affect growth and lipid synthesis (Rosebrough and McMurtry, 2000). T4 is the most dominant thyroid hormone in the circulatory system, but has a relatively small role in biological activity, while $\mathrm{T} 3$ has the potential to regulate protein metabolism and body fat in chickens (Kahl et al., 1998). It was reported by the researchers that there was very little effect of DOC weight on body weight gain, it was related to feed intake or consumption (Pinchasov, 1991; Wilson, 1991). This phenomenon associated with blood plasma levels is still unknown.

The success of broiler production depends on feed efficiency, breeders, and feed additives to increase efficiency. One of the additives added is a booster. Broiler booster is a complete supplement with a formulation consisting of vitamins, probiotics, amino acids, and minerals. Boosters for broilers are commercial feed additives. Each booster product produced by the factory has a diverse composition (Cibus, 2018). Therefore, this study aimed to determine the effect of adding a booster additive at different DOC body weight on the production performance of broiler.

\section{MATERIALS AND METHODS}

This research was conducted at the Field Laboratory of the Faculty of Animal Husbandry, Kanjuruhan University Malang, Pandan Wangi Village, Wagir District, Malang Regency. The research was conducted in July-August 2020.

\section{Animal and Feed}

The animal used in this study was the Cobb strain broiler (CP 707) raised in a closed house system in the Field Laboratory of the Animal Husbandry Faculty of Kanjuruhan University Malang, Pandan Wangi Village, Wagir District, Malang Regency.

DOC line CP-707 with a total of 96 birds unsex production of PT. Charoen Pokphand Jaya Farm. The feed given was complete feed produced by PT. Charoen Pokphand Indonesia Tbk. Feed was given ad libitum. Complete feed is given based on the production phase, include BR0 (1-7 days old), BR1 (8-21 days), and BR2 (>21 days). The chemical composition of the complete feed is presented in Table 1. The booster additive is a commercial product with the trade name NEOBRO. 
Table 1. Complete chemical composition

\begin{tabular}{lccc}
\hline Chemical composition & BR 0 & BR 1 & BR 2 \\
\hline Moisture (max.) & $14.0 \%$ & $14.0 \%$ & $14.0 \%$ \\
Crude protein (min.) & $22.0 \%$ & $20.0 \%$ & $19.0 \%$ \\
Ether extract (min.) & $5.0 \%$ & $5.0 \%$ & $5.0 \%$ \\
Fiber (max.) & $4.0 \%$ & $5.0 \%$ & $6.0 \%$ \\
Ash (max.) & $8.0 \%$ & $8.0 \%$ & $8.0 \%$ \\
Calsium & $0.8-1.10 \%$ & $0.8-1.10 \%$ & $0.8-1.10 \%$ \\
Phosphor (min.) & $0.5 \%$ & $0.5 \%$ & $0.45 \%$ \\
Total aflatoxin (max.) & $40 \mathrm{ppb}$ & $40 \mathrm{ppb}$ & $50 \mathrm{ppb}$ \\
\hline
\end{tabular}

Source: PT. Charoen Pokphand Indonesia

\section{House and Equipment}

House used was a closed house (tunnel system with evaporative cooling system). The equipment used were a digital scale, thermohygrometer, anemometer, AR8500 smart sensor, and clinical digital thermometer.

\section{Method}

The method used in this research was experimental. The research design was a factorial completely randomized design (CRD). About 96 chicks were randomly distributed in a factorial design; the first factor was the treatment of booster additives in commercially complete feed, namely $\mathrm{P}_{0}$ (without the addition of a booster) and $\mathrm{P}_{1}$ (with the addition of a booster), the second factor was the initial body weight of DOC which consists of three groups, include: light type 37-41.9 $\mathrm{g}\left(\mathrm{T}_{1}\right)$; medium type 42.0-46.9 $\mathrm{g}\left(\mathrm{T}_{2}\right)$; height type $>47 \mathrm{~g}\left(\mathrm{~T}_{3}\right)$ (Mendes et al., 2011). Chicken samples were reared in a pen (4 birds $/ \mathrm{m}^{2}$ ), feed and drinking water were given ad libitum. Data collection was carried out through observation of chicken samples in each experimental unit. In addition, data were obtained by direct measurement using a digital scale, thermohygrometer, anemometer, smart sensor AR8500, and a clinical digital thermometer. The data recorded daily were microclimatic data including temperature $\left({ }^{\circ} \mathrm{C}\right)$ and relative humidity (\%), wind speed (mph), and ammonia content (\%).

The tabulated data were feed consumption ( $\mathrm{g} / \mathrm{head})$, body weight gain $(\mathrm{g} / \mathrm{head})$, feed conversion, and production index. Analysis of variance (ANOVA) was used for data analysis and if the results differed significantly, the mean differences were tested using the Duncan Multiple Range Test (DMRT). Microclimate data were analyzed descriptively.

\section{RESULTS AND DISCUSSION}

The microclimate variables observed in this study included temperature, air humidity, and air velocity. The average microclimate variables are shown in Table 2.

The effect of using booster additives in broilers with different DOC body weights on the average feed consumption, body weight gain, feed conversion, and production index is presented in Table 3 .

Modern broiler breeders or entrepreneurs must be able to create appropriate environmental conditions to maximize its genetic potential, taking into account the most important factors in housing management and understand the basic operational guidelines for housing systems. The target temperature for the best broiler performance during the growing period is $30^{\circ} \mathrm{C}$ at one day of age and close to $20^{\circ} \mathrm{C}$ when approaching harvest age depending on the size of the poultry and other factors. Therefore, ventilation must be adjusted to achieve the optimal temperature for broiler maintenance. The temperature felt by birds depends on the ambient temperature and humidity. If the outside relative humidity is within the ideal range of $60-70 \%$, then the house temperature must be adjusted at every phase of production. It is necessary to monitor the behavior of the livestock to ensure that the birds feel the most comfortable temperature (Ross, 2010). 
Table 2. The average microclimate variables

\begin{tabular}{llrrr}
\hline Production & \multicolumn{1}{c}{ variables } & \multicolumn{3}{c}{ Observation Time } \\
\cline { 3 - 5 } \multicolumn{1}{c}{ Phase } & & $06: 00$ WIB & $12: 00$ WIB & $18: 00 \mathrm{WIB}$ \\
\hline Pre starter & Temperature $\left({ }^{\circ} \mathrm{C}\right)$ & 25.26 & 28.21 & 27.36 \\
$(1-7$ days) & Relative humidity $(\%)$ & 65.56 & 66.99 & 65.66 \\
& Air velocity $(\mathrm{ft} / \mathrm{min})$ & 80.29 & 61.38 & 72.00 \\
& Ammonia concentration $(\mathrm{ppm})$ & 0.00 & 0.00 & 0.00 \\
\hline Starter & Temperature $\left({ }^{\circ} \mathrm{C}\right)$ & 24.54 & 27.91 & 25.76 \\
$(8-21$ days) & Relative humidity $(\%)$ & 72.41 & 60.57 & 71.41 \\
& Air velocity $(\mathrm{ft} / \mathrm{min})$ & 90.57 & 112.93 & 117.64 \\
& Ammonia concentration $(\mathrm{ppm})$ & 2.58 & 1.36 & 1.86 \\
\hline Finisher & Temperature $\left({ }^{\circ} \mathrm{C}\right)$ & 22.15 & 27.72 & 24.60 \\
$(>21$ days- & Relative humidity $(\%)$ & 77.15 & 61.22 & 75.25 \\
harvest) & Air velocity $(\mathrm{ft} / \mathrm{min})$ & 246.00 & 246.17 & 252.67 \\
& Ammonia concentration $(\mathrm{ppm})$ & 0.83 & 2.20 & 1.32 \\
\hline
\end{tabular}

Table 3. The effect of using booster additives in broilers with different DOC body weights on the production performance

\begin{tabular}{llcccc}
\hline \multirow{2}{*}{$\begin{array}{c}\text { Additive } \\
\text { Booster }\end{array}$} & \multirow{2}{*}{$\begin{array}{c}\text { DOC } \\
\text { Weight }\end{array}$} & $\begin{array}{c}\text { Feed Consumption } \\
\text { (g/bird) }\end{array}$ & $\begin{array}{c}\text { Body weight } \\
\text { gain (g/bird) }\end{array}$ & $\begin{array}{c}\text { Feed } \\
\text { conversion }\end{array}$ & $\begin{array}{c}\text { Production } \\
\text { Index }\end{array}$ \\
\hline Without & Light & $3103.00 \pm 56.66$ & $2000.50 \pm 46.82$ & $1.55 \pm 0.05$ & $430.24 \pm 22.11$ \\
Additive & Medium & $3142.75 \pm 114.01$ & $1975.31 \pm 110.18$ & $1.59 \pm 0.05$ & $414.10 \pm 33.30$ \\
Booster & Heavy & $3080.25 \pm 122.16$ & $1938.12 \pm 50.14$ & $1.59 \pm 0.02$ & $406.59 \pm 5.53$ \\
\hline \multirow{2}{*}{ Additive } & Light & $3157.00 \pm 106.07$ & $1946.56 \pm 47.03$ & $1.62 \pm 0.03$ & $400.23 \pm 11.13$ \\
Booster & Medium & $3097.00 \pm 225.95$ & $2032.50 \pm 215.76$ & $1.53 \pm 0.13$ & $416.30 \pm 78.41$ \\
& Heavy & $3070.75 \pm 117.37$ & $1881.25 \pm 135.70$ & $1.63 \pm 0.08$ & $384.78 \pm 42.95$ \\
\hline
\end{tabular}

Note: Mean \pm standard deviation

The results of the observation of microclimate variables at the research location included temperature, humidity, and air velocity in the morning, noon, and the afternoon shows value according to maintenance standards at various phases of production. This closed house has an automated temperature control mechanism. Microclimate in accordance with maintenance standards will support the production process in the closed house. Air humidity in the house was in the range of $60.57-77.15 \%$. If the air humidity in the closed house was high it caused wet litter. The ideal humidity for raising poultry is 6080\% (PoultryHub, 2019).

Ammonia gas concentration in the cage is in the range of $0.0-2.58 \mathrm{ppm}$. Some of the gases that are harmful to poultry are $\mathrm{CO}_{2}, \mathrm{NH}_{3}, \mathrm{H}_{2} \mathrm{~S}, \mathrm{CO}$, and $\mathrm{SO}_{2}$. Ammonia is a metabolite produced by the bacteria in manures. Ammonia concentration in the house depends on ventilation, temperature, relative humidity, and livestock density. High concentration of ammonia causes irritation of the intestinal mucous membrane. The standard of ammonia gas concentration in the closed house in broiler rearing is $<25 \mathrm{ppm}(0.25$ vol \%) (PoultryHub, 2019).

\section{Feed consumption}

Based on the data analysis presented in Table 2 , there was no effect of adding a booster additive with different DOC body weight on feed consumption. The average feed intake with the addition of a booster treatment was equivalent to that of the feed treatment without the addition of a booster. The factors that influence energy consumption in poultry are species, genetic potential, age, and environmental conditions. Feed consumption is the main factor affecting body weight gain and feed efficiency of broilers. There are several feed 
factors that affect feed consumption, particularly if the composition of the feed exceeds or is less than required because broilers are selected for the purpose of body weight growth. They become less responsive to feed quality when compared to layer hens. Broilers tend to consume feed to maximize their digestive tract as long as it is not limited to the presence of toxic compounds, environment, management, and disease factors (Ferket and Gernat, 2006).

The protein and amino acid content of feed has an effect that does not directly influence feed consumption when compared to other factors. Poultry growth can be very sensitive to amino acid intake which has an impact on production when compared to the response to protein (Ferket and Gernat, 2006). Broiler booster is a complete feed supplement formulation that contains vitamins, probiotics, amino acid, and minerals. Sources of vitamins and minerals that have the maximum bioavailability are selected as constituents of feed booster additives. The modern and certified manufacturing process makes the booster additive to have maximum product quality. The ingredients contained in the booster must be guaranteed and traceable (Cibus. 2018).

\section{Body weight gain}

Based on statistical analysis. There was no effect of adding a booster additive with different DOC body weight on broiler body weight gain. It was reported by the researchers that there was very little effect of DOC weight on body weight gain. it is related to feed intake or consumption (Pinchasov, 1991; Wilson, 1991).

\section{Feed conversion}

Based on statistical analysis, there was no effect of adding booster additives with different body weight of DOC on feed conversion of broilers reared in closed house. Feed conversion is a calculation of the value of feed efficiency in converting feed into animal products. The factors that influence feed conversion are: feed quality, management, and bird health status. Broiler is genetically developed having a rapid growth rate. This can be seen from the performance of broilers from year to year (Thiruvenkadan, Prabakaran, and Panneerselvam, 2011). Currently broilers can reach a body weight of $2.2 \mathrm{~kg}$ in 35 days with a feed of $3.3 \mathrm{~kg}$ (Anonymous, 2017). The average conversion rate of treated feed without and with the addition of a booster was 1.5 .

\section{Production index}

The production index is a function of availability, live weight, feed conversion, and rearing time. Based on statistical analysis, there was no effect of adding booster additives with different DOC body weights on the feed conversion of broilers raised in closed houses. The average production index of the feed treatment without the addition of a booster additive was 416.98, while the treatment with the addition of a booster was 400.44. Unang et al. (2012) stated that the performance index (IP) of broiler farms in open house is around 340-360, while broiler production in closed house can achieved 400. Sasaki et al. (2014) stated that the factor affecting the broiler production index is the livestock density, parent age, and replacement frequency.

Wolanski et al. (2004) found a positive correlation between hatching weight and body weight at 6 weeks of age, regardless of the effect of gender differences. Hatching weight does not seem to predict the appearance of male broiler production. Other studies have shown conflicting results between hatch weight and subsequent production performance (Wilson. 1991; Tona et al. 2005). Egg weight may not be a good indicator of some production performance because there is no known amount of yolk residue. Wolanski et al. (2006) found that the amount of egg yolk residue varied between $0.8-10.6 \mathrm{~g}$. Wolanski et al. (2004) also showed a negative relationship between the amount of egg yolk residue and body weight without egg yolk residue. This indicates that DOC with large egg yolk residue has a low body mass compared with those without egg yolk residue. Yolk resude is an indicator of low 
body tissue development during the incubation process and this has an impact on further development.

\section{CONCLUSION}

The addition of a booster additive with different DOC body weight did not have an effect on feed consumption, weight gain, feed conversion, and production index on closed house rearing. It is suggested to conduct further research on booster additives with other DOC quality traits.

\section{REFERENCES}

Al-Murrani, W. K. (1978). Maternal effects on embryonic and post-embryonic growth in poultry. British Poultry Science, 19(3), 277-281. https://doi. org/10.1080/00071667808416476

Cibus. (2018). Broiler Booster. Cibus Animal Nutrition Ltd.

Decuypere, E., Tona, K., Bruggeman, V., \& Bamelis, F. (2001). The day-old chick: a crucial hinge between breeders and broilers. World's Poultry Science Journal, 57(2), 127-138. https://doi. org/10.1079/WPS20010010

Ferket, P. R., \& Gernat, A. G. (2006). Factors that affect feed intake of meat birds: A review. International Journal of Poultry Science, 5(10), 905-911.

Foster, D., Proudman, J., Harmon, S., \& Foster, L. (1997). Baculovirusmediated expression of chicken growth hormone. Comparative Biochemistry and Molecular Biology, 117(2), 233239. https://doi.org/10.1016/S0305-04 91(97)00046-1

Halevy, O., Hodik, V., \& Mett, A. (1996). The effects of growth hormone on avian skeletal muscle satellite cell proliferation and differentiation. General and Comparative Endocrinology, 101(1), 43-52. https:// doi.org/10.1006/gcen.1996.0006

Hill, D. (2001). Chick length uniformity profiles as a field measurement of chick quality. Avian Poultry Biology Reviews, 12(188).

Hodik, V., Mett, A., \& Halevy, O. (1997).
Mutual effects of growth hormone and growth factors on avian skeletal muscle satellite cells. General and Comparative Endocrinology, 108(1), 161-170. https://doi.org/10.1006/gcen. 1997.6964

Ípek, A., \& Sözcü, A. (2013). Broiler chick quality and scoring methods. Ziraat Fakültesi Dergisi, 27(2), 131-137. https://doi.org/10.20479/uuzfd.70293

Kahl, S., Rosebrough, R. W., \& Elsasser, T. H. (1998). Hepatic iodothyronine 5'monodeiodinase activity in the broiler chicken: Effect of dietary fat and triiodothyronine (T3) supplementation. Nutrition Research, 18(6), 1039-1047. https://doi.org/10.1016/S0271-5317(9 8)00086-4

Mafeni, M., Tivzenda, P. T., Briles, C. O., \& Lawrence, L. (1986). The response of egg size on early growth in white Plymouth Rock chickens. Journal Poultry Science, 65(85).

Meijerhof, R. (2006). Chick size matters. World Poultry Science Journal, 22, 3031.

Molenaar, R., Reijrink, I. A. M., Meijerhof, R., \& Van Den Brand, H. (2008). Relationship between hatchling length and weight on later productive performance in broilers. World's Poultry Science Journal, 64(4), 599604. https://doi.org/10.1017/S0043933 908000226

Morris, R. H., Hessels, D. F., \& Bishop, R. J. (1968). The relationship between hatching egg weight and subsequent performance of broiler chickens. British Poultry Science, 9(4), 305-315. https://doi.org/10.1080/000716668084 15726

Pinchasov, Y. (1991). Relationship between the weight of hatching eggs and subsequent early performance of broiler chicks. British Poultry Science, 32(1), 109-115. https://doi.org/10.10 80/00071669108417332

Poultry Hub. (2019). Climate in Poultry House. Poultry CRC.

Rosebrough, R., \& McMurtry, J. (2000). 
Supplemental triiodothyronine, feeding regimens, and metabolic responses by the broiler chicken. Domestic Animal Endocrinology, 19(1), 15-24. https://doi.org/10.1016/ S0739-7240(00)00060-6

Ross. (2010). Ross Management Handbook. Ross An Aviagen Brand.

Sasaki, Y., Uemura, R., Sekiguchi, S., Takahashi, T., Fujii, Y., \& Sueyoshi, M. (2014). An analysis of factors affecting production performance in broiler flocks on Japanese commercial farms. British Poultry Science, 55(6), 737-744. https://doi.org/10.1080/0007 1668.2014.966057

Tona, K., Bruggeman, V., Onagbesan, O., Bamelis, F., Gbeassor, M., Mertens, K., \& Decuypere, E. (2005). Day-old chick quality: relationship to hatching egg quality, adequate incubation practice and prediction of broiler performance. Avian and Poultry Biology Reviews, 16(2), 109-119. https://doi.org/10.31 84/147020605783438787

Unang, R., Nuryati, E., \& Sumarsih. (2012).
Kajian Pembiayaan Investasi Kandang Ayam Ras Pedaging Dalam Rangka Meningkatkan Kesejahteraan Peternak Rakyat Pada Pola Usaha Mandiri. In Memitraan dan Makloon. Informasi Studi Banding Klaster Ayam Ras Pedaging Priangan Timur.

Whiting, T. S., \& Pesti, G. M. (1984). Broiler performance and hatching egg weight to marketing weight relationships of progeny from standard and dwarf broiler dams. Poultry Science, 63(3), 425-429. https://doi. org/10.3382/ps.0630425

Wilson, H. R. (1991). Interrelationships of egg size, chick size, posthatching growth and hatchability. World's Poultry Science Journal, 47(1), 5-20. https://doi.org/10.1079/WPS19910002

Wolanski, N. J., Luiten, E. J., Meijerhof, R., \& Vereijken, A. L. J. (2004). Yolk utilisation and chick length as parameters for embryo development. Avian and Poultry Biology Reviews, 15(3), 233-234. https://doi.org/10.31 84/147020604783637877 